\title{
Environmental Protection and Political Borders: NATURA 2000 in the Rhodope Mountains
}

\author{
Çevre Koruma ve Siyasi Sinırlar: Rodop Dağları'nda Natura 2000
}

\author{
Assen ASSENOV \\ Landscapes and Environmental Protection Department \\ University of Sofia "St. Kliment Ohridsky”, Faculty of Geology and Geography
}

\begin{abstract}
In the summer and autumn of 2011 two surveys of habitat types were conducted in "Dolna Mesta" $B G 0000220$ protected site. During the field studies, in addition to the description of habitat types, measurements of specific characteristics of landscape were carried out. They were followed by cameral work using Global Mapper Program when the final values were derived and summarized as morphometric characteristics of Perica Mountain. From the field studies along the boundary line immediate information about the nature of the relief in the upper part of the southern macro-slope and the conservation value of habitat diversity in this part of the mountain was obtained. Furthermore, a previous visit of the Greek part of the Bozdag Mountains (2009) provided immediate information on relief and habitat diversity at the foot of the Perica Mountain. The deficit of field studies in Greece was compensated by using the Google Earth Program. The current study aims to determine the conservation significance of the Bulgarian part of Perica Mountain, part of "Dolna Mesta" protected site and compare it with the southern macro-slope of the same mountain, located in Greece. Comparison of conservation value between the two macro-slopes of the mountain is particularly important because the ridge follows the border between two countries of the European Union. The question arises why the Bulgarian part of Perica Mountain is a protected area, and the Greek part is not? This may affect the principles and specific criteria for the designation of protected NATURA 2000 sites in the different EU-member countries. The issue is related to the quality and quantity of ecosystem services (landscape services) provided by the Bulgarian and Greek part of the mountain, because there is no difference in the conservation value of the two slopes except for the fact that the Greek one is twice as large as the Bulgarian.
\end{abstract}

Key words: NATURA 2000 sites, habitat and birds protected sites, habitat types, conservation value, ecosystem services.

Özet: 2011 yaz ve sonbahar mevsimlerinde "Dolna Mesta" BG 0000220 koruma alaninda habitat tipleri ile ilgili iki araştırma düzenlenmiştir. Habitat tiplerinin tanımlanmasına ek olarak arazide ölçümler yapılmıştır. Global Mapper yazılımı kullanılarak elde edilen dĕgerler Perica Dağı'nın morfometrik özellikleri olarak değerlendirilmiştir. Arazi çalışmalarından sınır boyunca güneye bakan yamaçların üst bölümlerinin rölyefi ile ilgili doğrudan veri elde edilmiş ve dağın bu kesimindeki habitat çeşitliliği saptanmıştır. Ayrıca, daha önce gidilen Bozdağlar'ın Yunanistan'daki bölümünde Perica Dağl'nın eteklerindeki habitat çeşitliliği ve rölyef hakkında bilgi sağlanmıştır. Yunanistan'daki arazi çalışmalarının azlı̆̆ Google Earth yazılımı kullanılarak giderilmiştir. Bu çalışmanın amacı Perica Dağı'nın Bulgaristan bölümünde, "Dolna Mesta" koruma alanında korumanın öneminin saptanması ve aynı dağın Yunanistan'da kalan bölümü ile güney yamaçlarının karşılaştırılmasıdır. Özellikle dağın iki yamacının koruma değerlerinin karşılaştırılması önemlidir çünkü dăg sırası Avrupa Birliği üyesi iki ülkenin sınırını takip etmektedir. Burada ortaya çıkan soru, neden Perica Dağı'nın Bulgaristan bölümünde kalan kısmı koruma altındayken Yunanistan'daki tarafı değildir? Bu durum farkl AB ülkelerinde NATURA 2000 alanlarının koruma düzenlemelerindeki özel koşullart ve prensipleri etkileyebilir. Konu dağın Yunanistan ile Bulgaristan'daki bölümlerindeki ekosistem hizmetlerindeki kalite ve nicelik ile ilgilidir çünkü Yunanistan tarafinın Bulgaristan'dan iki kat geniş olduğu gerçeği dışında iki yamaçtaki koruma değerleri arasında fark yoktur.

Anahtar sözcükler: NATURA 2000 alanlart, habitat ve kuş koruma alanlarl, habitat tipleri, koruma değerleri, ekosistem hizmetleri. 


\section{Introduction}

NATURA 2000 protected areas ecological network is the fundamental spatial structure in the European Union for the conservation of environment aiming to ensure the quantity and quality of ecosystems (landscape) services that nature provides to society. The philosophy of habitat diversity and ornithologically important areas is defined by the Habitats Directive 92/43 of the EEC and the Birds Directive 79/409 but the concrete specifics of the protected areas in the NATURA 2000 ecological network has its peculiarities in each member country of the European Union.The chronological differentiation in the accession of the member countries to the EU is reflected in the formation of the ecological network NATURA 2000, expressed in spatial fragmentation and often the defining of boundaries of protected areas is according to national borders and sometimes to internal boundaries between regional units.

The author of this study was involved as a senior expert in verification and mapping of habitat types in the protected areas Dolna Mesta BG 0000220 and Rhodopes West BG 0001030.The conducted field research in the summer and autumn of 2011 and 2012 raised many questions about the spatial range of NATURA 2000 protected areas located on both sides of the border between Bulgaria and Greece and their interpretation is discussed in the article. Establishing optimal trans-border corridors in the NATURA 2000 ecological network (e.g. with Turkey in the near future) is particularly important and the example with the current survey aims to illustrate the discrepancies of the Bulgarian - Greek border area related to fragmentation or lack of spatial continuity in the areas on both sides of national borders.

\section{Material and methodology}

The EU Habitats Directive (Council Directive 92/43 EEC.1992) and Birds Directive (Council Directive 79/409 EEC.1979) are of greatest significance in the EU environmental policy from the point of view of the value of natural capital. Within the NATURA 2000 ecological network Republic of Bulgaria so far has 231 sites (Sites of Community Importance (SCI)) under the Habitats Directive and 118 protected areas (Special Protected Areas (SPA)) under the Birds Directive while the Republic of Greece has 241 sites (Sites of Community Importance (SCI)) under the Habitats Directive and 202 protected areas (Special Protected Areas (SPA)) under the Birds Directive.

Republic of Bulgaria covers $110,910 \mathrm{~km}^{2}$, of which $30 \%$ are part of the habitat protected areas (Sites of Community Importance (SCI)) and $22 \%$ are part of protected areas for birds (Special Protected Areas (SPA)), thus the protected area under the two Directives includes 336 sites which cover $34.3 \%$ of the country's territory.The territory of Greece is $131,940 \mathrm{~km}^{2}$, of which $22 \%$ are part of habitat protected areas (Sites of Community Importance (SCI)) and $22.6 \%$ are part of protected area for birds (Special Protected Areas (SPA)) or totally the protected area under the two Directives includes 443 sites which cover $33.4 \%$ of the territory of the country. In relative share of NATURA 2000 ecological network in the national territory Bulgaria and Greece along with Spain, Cyprus, Slovenia and Slovakia rank among the EU member states with the highest share.

The perception that protected natural areas in Europe would guarantee directly to the European Union and indirectly to the rest of the world the maintenance of the quantity and quality of ecosystem (landscape) services is the foundation of the NATURA 2000 ecological network. In that context the main objective of thes study is to highlight some spatial problems of protected areas along the border between Bulgaria and Greece as a result of the existence of the national boundary. The meaning of such a study is related to the unification of criteria for the designation of protected natural areas and their future management especially in border areas between new and old EU member states. Providing quality ecosystem (landscape) services largely depends on the spatial subordination of the respective areas in terms of configuration, content and relationships, regardless of frontiers in Europe, even with the members outside of the Schengen area. 
Surveys were conducted twice on the habitat types of the protected areas Dolna Mesta BG 0000220 and Rhodopes West BG 0001030 in the summer and autumn of 2011 and 2012. In addition to the description of habitat types during the field survey, measurements of certain characteristics of the terrain were made, on the basis of cameral conditions using Global Mapper Program, where the final values were derived and summarized in morphometric characteristics of a mountain, named Perica (Assenov, 2012).

The northern macro-slope of Perica Mountain is almost entirely located on Bulgarian territory and is part of a protected area under the Habitats Directive - Dolna Mesta BG 0000220.The southern macro-slope of the same mountain is in the Greek territory, where there is not any protection statute in the area.The geographical area of the Perica Mountain is one of the areas on the border between Bulgaria and Greece, where the Bulgarian section is a protected area and the Greek section is not under protection. Therefore the geographic space of Perica Mountain was chosen as a key location illustrating the disparity between the northern and southern macro-slopes of a mountain, on the ridge of which lies the national boundary and the northern macro-slope is a NATURA 2000 site, while the southern macro-slope does not fall in any protected area. During the field research of Perica Mountain along the state border, direct information on the nature of the relief in the upper part of the southern macro-slope and the conservation value of habitat diversity in this part of the mountain was obtained. Furthermore, during a previous visit to the Greek border territory in the Bozdag Mountain (2009) clear idea of the character of the terrain and the habitat diversity of the southern foothills of Perica Mountain was received. Insufficient field studies on Greek territory are supplemented with information provided by Google Earth Program.

The designation of protected areas within NATURA 2000 network is based entirely on scientific criteria, reflecting the environmental quality and natural habitat area. The text of Directive 43/92 stipulates that "the Directive does not include rules for the selection of protected areas for habitats and species (SCI)". "EU member states decide the issue on their own judgement". These texts give some freedom to individual countries to decide which natural geographic areas to select as sites of community importance (SCI) depending on the specific environmental conditions, as well as on cultural and historical reasons. The understanding that conservation is by definition international endeavor, because habitats and species do not recognize state borders, requires some optimization of the spatial structure of the sites of community importance (SCI) between member states. The integrated international approach embodied by NATURA 2000 ecological network is an example of such action. Directive 43/92 by creating sites of community importance (SCI) ensures that in the space of the European Union ecosystem (landscape) services are delivered in such quantity and quality to guarantee environment-friendly and healthy conditions for people. From this point of view the question arises why the Greek NATURA 2000 protected area Central Rhodope Mountains and the Mesta River Valley GR 1140008 spreads until the Mesta River Valley and does not encompass the southern slopes of Perica Mountain?

\section{Habitat diversity of Perica Mountain}

The field research carried out in the Bulgarian part of the Perica Mountain revealed the presence of habitat types with well-preserved structure and lack of short-term perspective for negative changes. The height distribution of the vegetation in the mountain, according to the most accurate scheme (Bondev, 1991) shows its appurtenance to the xerothermic oak belt and mesophilic oak and hornbeam forests belt (hornbeam-durmast belt). Among the forest habitat types of European importance in the mountain, the following two are definitely presented - 91M0 "Balkan-Pannonian oak-durmast forests", height attached to the xerothermic oak belt but in places reaching the summit of the mountain, and 9170 "Oak-hornbeam forests of Galio-Carpinetum type ", which are common in the higher part of the mountain, closer to the ridge or deep ravines. There is no clear boundary between the two habitat types and they often blend into each other and in places form complexes. 
According to the verification model of habitat types below the Chiplak Bair Peak (1091 m) - the highest point of the mountain (Figure 1), a small area of habitat type 9530 "Sub-Mediterranean pine forests with endemic black pines" is indicated which during the field research was not found. In the eastern part of the mountain around pyramid № 157 communities of black and white pine between 40 and 50 years of age are preserved which are essentially planted and young trees of them are spread, including on Greek territory. Although the forest was created by man, it is in very good condition and keeping to the requirements of Directive 43/92 it can be attributed to habitat type 9530. The area east of Tumba Peak $(805 \mathrm{~m})$ towards the border line, as large as about $3 \mathrm{~km}^{2}$, is excluded from Dolna Mesta site, but as mentioned above the area is occupied by well-preserved planted coniferous forests that may be regarded as part of habitat type 9530. The likely reason for the exclusion of this territory from the protected site could be that it was preserved as hunting ground for the local hunter' group in the village of Beslen and during the field research primitive hunting infrastructure with traces of the hunters'activities was found.

Field studies have shown that since 2006 there are no traces of forestry logging and forest poaching is even less manifested. It is necessary to mention that traces of illegal cutting are observed around the border on the Greek territory and clearly it is done by Bulgarian poachers as the nearest Greek village of Lefkogia (Belotintsi) is located $8 \mathrm{~km}$ from the border line, while the Bulgarian village of Teplen is only one km away (Figure 1). This hypothesis was confirmed by a forestry representative explaining that poachers cannot be sanctioned because the logs obtained come from Greek territory. A general feature of forest vegetation in the Bulgarian part of Perica Mountain is its low stem character and the clear felling carried out in the past have caused the appearance of shrub communities of juniper. Habitat type 5210 "Arborescent matorral with juniperus spp." (Temperate heath shrubbery with Juniperus spp.) is distributed along the right valley slope of Dalboki Dol River (Figure 1), a right tributary of Matnitsa River and reaches the crest of the hill (at elevation $854 \mathrm{~m}$ ) that descends from the border pyramid № 136 on the mountain ridge $(862 \mathrm{~m})$.Small space of the same habitat is found on the mountain ridge below Pechutsa peak $-848.5 \mathrm{~m}$ (Figure 1), one $\mathrm{km}$ from the displaced Perica village. Also small in size is the area of this habitat in the spring area of Petraliksko Dere River in "Vrachkina water" locality. Significantly larger is the area of the same habitat 5210 in the Petralikski Gorge of Matnitsa River, covering the right valley slope between the river and the location of the former border facility.In this region, habitat type 5210 forms a complex with habitat type 6210 "Semi-natural dry grassland and shrub communities on calcareous substrates (Festuco-Brometalia). Beyond Domuz River Valley, in the valley of the next right tributary of Matnitsa River, on the right slope, juniper communities are developed that have emerged after the clearing of the oak forest of habitat type $91 \mathrm{M} 0$.

Grassy habitat 6210 is widespread near Mesta River, especially around the villages of Petralik, Beslen and Teplen,and similar to the habitat locations on the left valley slope of Mesta River outside the studies area, is very close to former or current fields occupied by tobacco culture. One kilometer from Mesta River at the eastern end of the mountain the rocky habitat type 8220 is appointed, which was not verified during the fieldwork. The habitat diversity in the Bulgarian part of the mountain includes also habitat type "Alluvial forests with Alnus glutinosa and Fraxinus excelsior" 91EO developed along Mesta River, but significantly changed and in much worse condition than the same riverside forests across the border with Greece. 


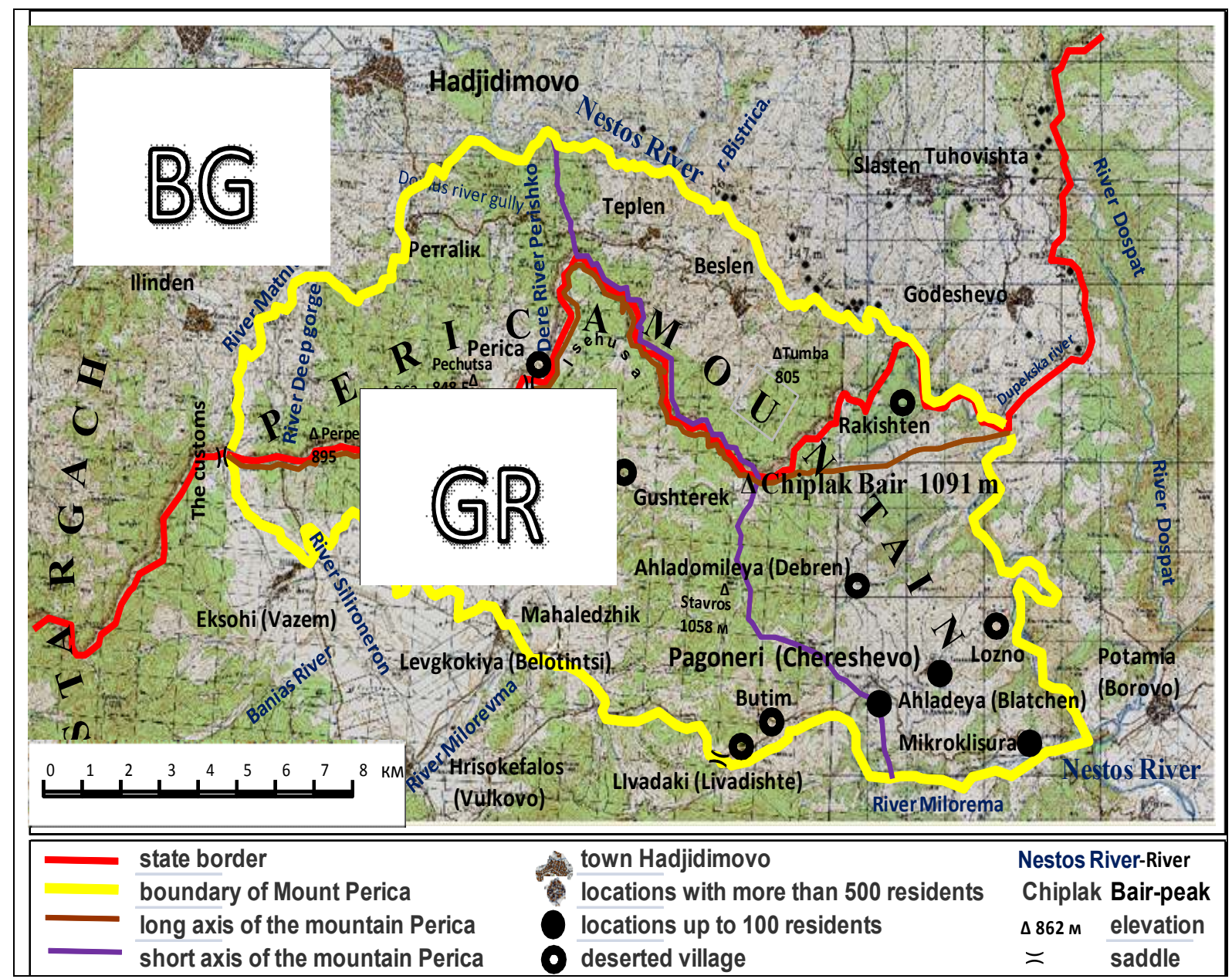

Figure 1. Morpho-hydrographic map-scheme of Perica Mountain

Although the habitat types on the northern macro-slope of Perica Mountains within the Republic of Greece have not been specifically studied,inn general without detailed spatial localization, habitat diversity is structured as follows:immediately after the summit of the mountain still there exists a complexof habitat types $91 \mathrm{M} 0$ and 9170, which unlike the northern slope here are in very good condition. Habitat type 9170 is similarly attached to deep shady ravines while $91 \mathrm{M} 0$ is widespread on open spaces. In the latter habitat exemplars of Quercus daleschampiiare found, that are 70-80 years old with good vital characteristics. On the southern side of the slope near the crest young trees of white and black pine occur that appeared from self-spread diasporas of the artificial pine plantations established on Bulgarian territory. At the southern foothills of Perica Mountain and especially in the arid habitats in the southeastern part of the mountain around the deserted village of Debren (Figure 1) there are spaces occupied by habitat type 91AA "Eastern oak forests". It is very likely that within this habitat exemplars of parnar - Quercus coccifera, could be found, since information about that was received by the local population. Even if there are separate exemplars of parnar - Quercus coccifera, they do not justify the existence of a habitat type 934A, which is developed massively to the south of Gyuredzhikska Saddle far beyond Perica Mountain. At the southern foot of Perica Mountain considerable space is occupied by grasslands, representing part of habitat type 6210, which in places form a complex with the shrubs of juniper from habitat type 5210. On the solid rocksin the Greek part of the Chechki Gorge of Mesta River (Figure 1), particularly in the land of Pagoneri village (Chereshevo) chasmophytic communities forming part of the habitat type 8220 are developed. In the Bulgarian part of the Chechki Gorge of Mesta River there are no well preserved communities of plane 
tree, thus habitat type 92S0 cannot be specified, but on the Greek territory near Mesta River, which is the eastern border of Perica Mountain definitely there are spaces that form part of habitat type 92S0. These riparian communities are mixed with habitat type "Alluvial forests with Alnus glutinosa and Fraxinus excelsior" $91 \mathrm{EO}$ widely developed along the banks of Mesta River in the Greek part of Chechki Gorge.

\section{Results}

Republic of Bulgaria is one of the countries in the EU that has significant taxonomic floral biodiversity set at 4,030 vascular plants (Petrova and Vladimirov, 2010). The diversity of endemic flora in Bulgaria includes 444 species of vascular plants, of which 270 species are Balkan endemics and 174 species are Bulgarian endemics (Petrovaand Vladimirov, 2010). These authors point out that the Rhodope Mountains have 201 endemic floral species, of which 146 species are Balkan endemics and 55 species are Bulgarian endemics. The elaborated list of Bulgarian habitats contains 977 habitat types from all hierarchical levels. At the elementary level the number is 542. A total of 96 habitats are found only within the territory of Bulgaria (Meshinev and Apostolova, 2005). Perica Mountaindirectly adjoins the Rhodopes and in terms of geotectonic structure is part of the Rhodopes. It is used as an example toillustrate the qualitative features of this area, of which only the northern slope is part of a protected area $(\mathrm{SCI})$.

Greece has a very rich flora, one of the richest in the EU and according to Dimopoulos et al. (Pers. comm. 2012: Checklist of the Vascular Plants of Greece, currently in progress), it consists of 7,000 taxa of flora (native and naturalized alien), while according to Strid and Tan (1997, 2002), Tan and Iatrou (2001), the estimated number of floral taxa in Greece is respectively 6437 and 5800 species. Endemic flora diversity in Greece is among the highest in Europe and the Mediterranean, and includes 913 endemic species (Georghiou and Delipetrou, 2010). In regard to habitat diversity it can be assumed that the 270habitat types appointed for the Mediterranean biogeographical region (according to EEC) are also spread in Greece although the official website of NATURA 2000 in Greece indicates the existence of 92 habitat types that are probably part of a group of habitat types of European conservation importance. Providing data on the genealogical and functional biodiversity of Greece it is worth emphasizing the richness of this European country which is by only $20,000 \mathrm{~km}^{2}$ larger than Bulgaria. Moreover, much higher rates of taxonomic diversity of Greek flora can be accepted, which is likely based on the specific geographic conditions of the country expressed in the prevailing mountainous relief and $90 \%$ of the country's pertaining to the biome of the "Mediterranean forests and shrubs" - Durilignosa. The fact that a large part of Greek's territory is comprised of islandscomplements a similar argument as geographical isolation undoubtedly stimulates active species-formation processes and such examples on islands of Greece are provided (Grant, 1985).

In that context the question arises why the Greek NATURA 2000 protected site Central Rhodope Mountains and the valley of Mesta River GR 1140008 extends till the Mesta River valley and does not expand along the southern slopes of Perica Mountain (Figure 2)? If we follow the southern Bulgarian boundary with Greece will shall notice several peculiarities in the distribution of NATURA 2000 protected areas. From east to west at Svilengrad due to Maritsa River there are protected areas on both sides of the border, and towards Gorata Hill in the Eastern Rhodopes both on Bulgarian and Greek territory there are no protected areas, probably because the river terraces have been long ago utilized for agricultural purposes. 


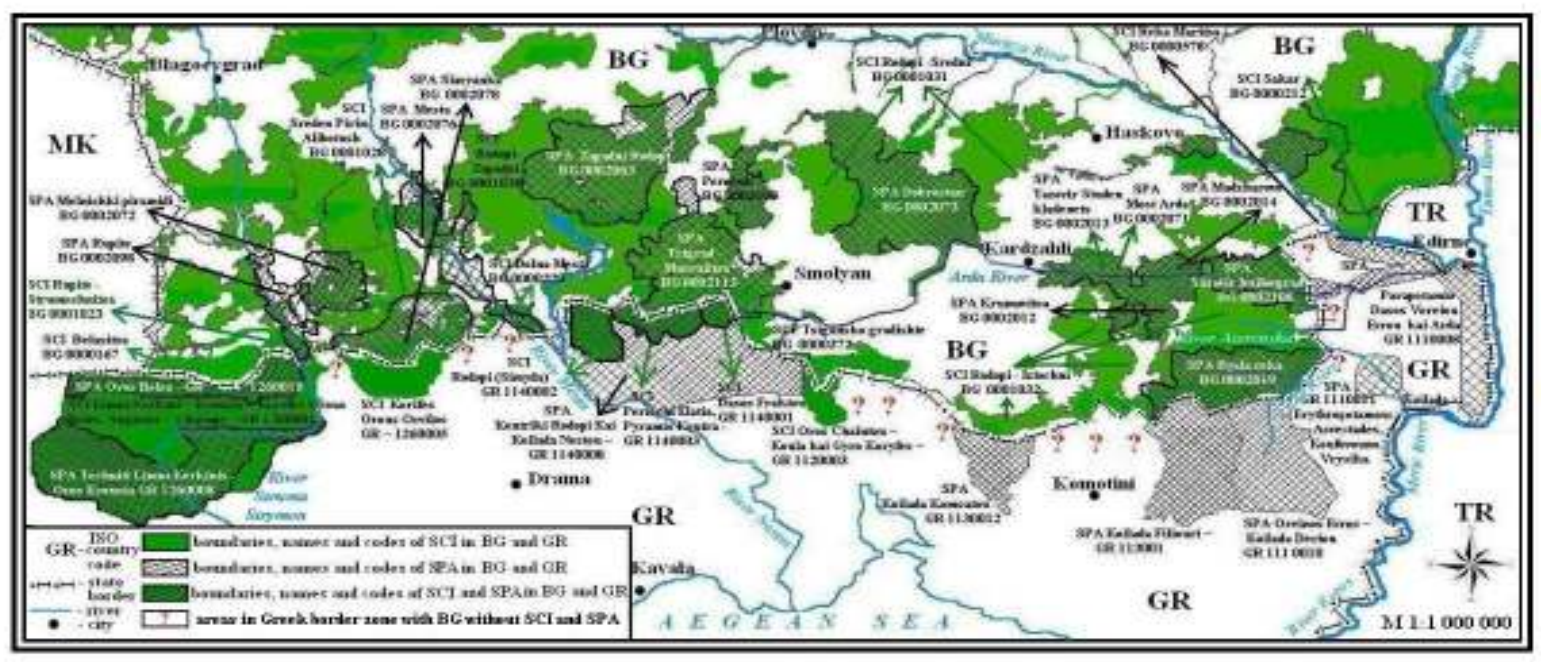

Figure 2. Distribution of NATURA 2000 protected sites on the border between Bulgaria and Greece

In the Greek territory of the Maritsa River Valley protected area only appears around the valley of Arda River (SPA, Parapotamio Dasos Voreiou Evrou kai Arda GR 1110008), towards the Bulgarian border village of Gorno Lukovo no protected area exists and the Greek protected area along Maritsa River ends northeast of Didymoticho (Didymoteicho). In this section of the border line all the Bulgarian territory is under protection, with the only exception of the territorybetween the villages of Slaveevo and Belopolyane (Ivailovgrad) but the strip of land along Aterenska River, which is part of the Eastern Rhodopes BG 0001032protected area cuts into the outlined territory. This is the only part of Eastern Thrace which remained within the boundaries of modern Bulgaria, and it is also very fertile and has been long ago utilized by farmers. There is no argument why along the smallAterenska River in Bulgaria a protected site is outlined (it is part of the Eastern Rhodopes BG 0001032 protected area) while in Greece such is absent. Similarly in Bulgaria a protected area is defined along the bigger border river - Luda River, while in Greece a protected area is set only on the right bank of the same river, which has a common border of about $15 \mathrm{~km}$ with the Greekprotected area for birds named Koilada Erythropotamou: Asvestades, Koufovouno, Vrysika GR 1110011 (Figure 2).Continuing west of Gorno Lukovo village to the spring area of the Bulgarian Krumovitsa River on both sides of the border extensive protected areas are established.The Bulgarian protected area is Eastern Rhodopes BG 0001032, and in Greece there are two protected areas for birds, namely Oreinos Evros - Koilada Deriou GR 1110010 and Koilada Filiouri GR 113001 (Figure 2 and Figure 3).On Greek territory to the west from the spring area of Krumovitsa River towards Veikata Peak the area is not protected and on Bulgarian territory this space falls within Eastern Rodopi BG 0001032. From the appointed peak to Tri kamaka Saddle on Greek territory spreads the protected area Koilada Komsatou GR 1130012, but on Bulgarian territory in the section from the boundary of Kardjali regionuntil the village of Erma reka in Smolyanregion no protected areas are established. There is no single explanation for that - the reason could be either the very changed environment around the former Erma reka mine or the regional boundary between the Kardzhali and Smolyan regions has an impact on the disruption of the territorial connectionof protected areas on Bulgarian territory.In the Greek territory from Tri kamaka Saddle to Tsigansko Gradishte Peak $(1827 \mathrm{~m})$ no protected area is established while in Bulgaria in this section of the border area lies the habitat protected area Tsigansko Gradishte BG 0000372.In Greece around Tsigansko Gradishte Peak the habitat protected area Oros Chaintou - Koula kai Gyro Koryfes GR 1120003 is formed. From Tsigansko Gradishte Peak $(1827 \mathrm{~m})$ to the west until the valley of Mesta River the Greek territory is continuously protected area. It includes the following habitat conservation 
areas: Dasos Fraktou GR 1140001; Periochi Elatia, Pyramis Koutra GR 1140003 and Rodopi (Simyda) 1140002, with no spatial relationship to each other, but they all come within the considerable range of the Greek protected area for birds Kentriki Rodopi Kai Koilada Nestou GR 1140008.In Bulgaria, the territory from Tsigansko Gradishte Peak until the springs of Arda River is not under protection. Similarly to the case with Aterenska River, here the Smilyanska River valley, being part of a protected area, cuts through the center of the Bulgarian border area without protected zones, specified above.

From the springs of Arda River until Dospat River the huge Bulgarian habitat protected area Rhodopes BG 0001030 stretches, which largely coincides with the Bulgarian protected area for birds Trigrad - Mursalitsa BG 0002113. On Bulgarian territory the habitat protection area along the border with Greece unnaturally ends at Dospat River valley, at the point where the river for about $3 \mathrm{~km}$ is a national border. The border area of Dospat River has been particularly studied by a team of scientists, including the author of this article (Assenov et al., 2012) and clear assessment was made that Dospat River Valley should be included in one of the two Bulgarian habitat protected areas - Rhodopes BG 0001030 or Dolna Mesta BG 0000220.The disruption of NATURA 2000 network at Dospat River valley is related to the existence of regional boundarybetween Smolyan and Blagoevgrad regions and the requirement for future management of protected areas, which could be problematic as appointed territory is the most extreme periphery in both regions.

On Greek territory from the valley of Mesta River to Slavyanka Mountain no protected area exists.It is justified for the area around Ilinden - Eksohi border check-point, where in Bulgaria the two habitat protected areas DolnaMesta BG 0000220and Middle Pirin - Alibotush BG 0001028 are territorially disconnected, but the protected area Dolna Mesta actually could naturally continue on Greek territory encompassing thesouthern macro-slope of Perica Mountain, discussed earlier in this article, as a typical example of the violation of the natural connection between the sites of the NATURA 2000 ecological network. The example is even more dramatic provided the fact that from the Mesta River valley to Struma River valley in Greece there is only one protected area -Korifes Orous Orvilos GR 1260005. To the west of the just mentioned Greek habitat protected area till the Struma River valley there is lack of protected territories and from the valley of Struma River to the west the Greek habitat protected area Limni Kerkini - Krousia - Koryfes Orous Beles, Angistro Charopo GR 1260001 is situated, which continues in western direction after the three-border Tumba Peak $(1880 \mathrm{~m})$, and to some extent overlaps with the protected area for birds Oros Beles GR 1260010.

From the Mesta River valley to the three-border Tumba Peak on Bulgarian territory severalhabitat conservation areas alternate: DolnaMesta BG 0000220, Middle Pirin - Alibotush 0001028, Rupite - Strumeshnitsa BG 0001023 and Belasitsa BG 0000167, which in many places largely overlap with the Bulgarian protected areas for birds: Mesta BG 0002076, Slavyanka BG 0002078 and Rupite BG 0002098.Throughout this space in Bulgaria there is almost full coverage of protected areas of NATURA 2000, which in very few places and quite limited are interrupted - as mentioned at the check-border point Ilinden - Eksohi, small border areas east of Tumba Peak ( $805 \mathrm{~m}$ asl), in Mountain Perica (mentioned as hunting ground) and small area in Slavyanka Mountain south of Petrovo village (probably also for hunting purposes). 


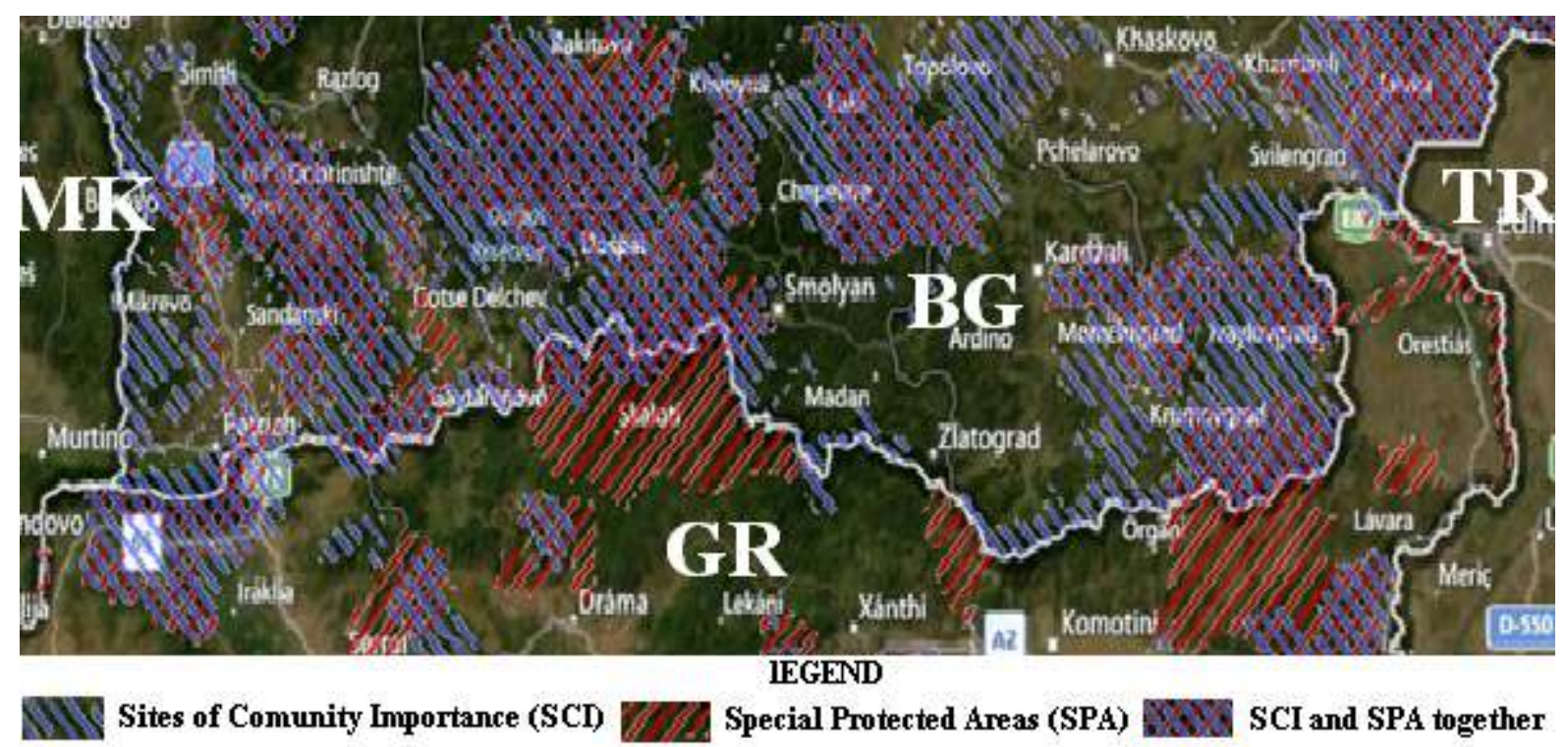

(Source: NATURA 2000 interactive map - European Environmental Agency)

Figure 3. Protected area on Greek - Bulgarian border

\section{Discussions}

Freedom that Directive 43/92 provides to the member states to set their own protected sites predetermines the individual approach to the designation of protected areas in each country. The idea that environmental protection is an international endeavor is contrary to the above described situation on the border between Bulgaria and Greece which illustrates that frontiers between EU Member States are dividing (disjunctive) factor in terms of NATURA 2000 protected areas.The full name of this initiative is "NATURA 2000 ecological network" and the discrepancies between Bulgaria and Greece along the state border show considerable differences in the approach of the two countries, and especially in Greece we can hardly justify the existence of a network. Moreover, the conjunction of these continental sites (according to the biogeographical regionalization of the European Environmental Commission) may only be made northwards through Bulgarian territory because to the south lies another biogeographical region. It should be noted that the border between the two countries coincides roughly with the boundary between two major land biomes. Thus, the area is essentially a biogeographical ecotone that can be differentiated into phytogeographic, zoogeographical, floral and faunal ecotone or adversely - in direction of consolidation of environment - as natural or landscape Mediterranean ecotone. Transfusion of some habitat types typical for the communities of the biome "Summer-green forests and shrubs" - Aestilignosa to other habitat types that are part of the biome"Sclerophyllus forests and shrubs" - Durilignosa and the existence of coniferous forests in the high mountains, which are a mixture of the biome "Coniferous forests and shrubs" - Aciculilignosa and the Mediterranean-type coniferous communities require a more precise assessment of the range and spatial structure of protected areas in the region.

Greece accessed the EU in 1981, and the formation of Greek NATURA 2000 network of protected areas began in 1994-1995, but some of them are established and/or updated recently, as follows:

- Koilada Komsatou GR 1130012 and Parapotamio Dasos Voreiou Evrou kai Arda GR 11100 are declared in 2002;

- Koilada Filiouri GR 113001 is created in 2002, but is updated in 2009; 
- Oreinos Evros - Koilada Deriou GR 1110010 is announced in 2005 and updated in 2009;

- Oros Beles GR 1260010 protected area for birds is established in 2001 and updated in 2009;

- Koilada Erythropotamou: Asvestades, Koufovouno, Vrysika GR 1110011 is declared in 2009.

Comparing the years of establishment of the Greek NATURA 2000 protected areas along the state border with Bulgaria we can make some conclusions which are particularly important for the countries that will be involved in the future enlargement of the EU. In Greece there is an active period in relation to protected areas establishment in the period $1994-1995$, probably dictated by the European Environmental Agency. After the accession of Bulgaria to the EU in 2007 Greece had to reassess the status of the border area with Bulgaria as part of NATURA 2000 ecological network. The most northern geographical areas of Greece are sparsely populated and remain on the periphery of Greece itself, but have very well preserved nature. Already neighboring a new EU country in 2009 Greece updated almost all of its protected areas along the border with Bulgaria. A new protected area Koilada Erythropotamou: Asvestades, Koufovouno, Vrysika GR 1110011, was established, which although not reaching the border with Bulgaria is located in close proximity.

Bulgaria within a few years after the accession to the EU was able to form its NATURA 2000 ecological network and almost the full coverage of the territory close to the border with Greece with protected areas from the ecological network is due to the mountainous terrain and unspoilt nature. In terms of future enlargement of the European Union more dynamic and strict rules to the newly accessing countries should be enforced, which should be in the form of requirements to be fulfilled in the preparation period.

In tracing the protected areas on Bulgarian border territory with Greeceit is noteworthy that two of the three disruptions in the spatial range of the Bulgarian NATURA 2000 protected areas are related to the existence of regional boundaries between Kardzhali and Smolyan regions and between Smolyan and Blagoevgrad regions. This example illustrates that regional boundaries seem to be an important factor in the formation of protected areas in Bulgaria that might be as well related to responsibilities in the future management of the established protected areas.

Article 30, paragraph 2 of the Biological Diversity Act (2002) says that "To ensure the links between the special areas of conservation, the plans and projects referred to in Paragraph (1) shall include measures and activities for conservation of the features of the landscape which, by virtue of their linear and continuous structure or their function as stepping stones, are essential for the migration, dispersal and genetic exchange of plant and animal populations and species ". This paragraph of the Biological Diversity Act shows that the current boundaries of protected areas between the above discussed administrative regions is in violation of the law. Analysis of the administrative details related to the protected areas in northern Greece needs time and effort that goes beyond the present paper. It is necessary to be noted that the discussed problem in Greece is more general, as our southern neighbor has seen the border with Bulgaria as peripherals and seeks to preserve spaces for economic revitalization of these until recently very distant and isolated areas. Future regional development in the Balkans would imply "changes in structure and regional policy and the focus should be on sustainable economic benefits arising from the use of regional advantages related to the environment" (Borissovaand Koulov, 2010).

\section{Conclusions}

The geographical analysis of the location of NATURA 2000 protected areas along the state border between Greece and Bulgaria, which roughly coincides with the Mediterranean biogeographic biome and landscape ecotone, illustrated the high indicators of genealogical and functional nature of biodiversity and imposes the following conclusions: 
- The state border between Bulgaria and Greece is a limiting factor in determining NATURA 2000 protected areas and the internal regional borders in Bulgaria are also a limiting factor in the outlining of these areas in Bulgaria, which contradicts the general philosophy underlying NATURA 2000 ecological network.

- Out of the total length of the border line between Bulgaria and Greece (493 km) in Bulgaria approximately $390 \mathrm{~km}$ fall in NATURA 2000 protected areas, while on Greek territory only $175 \mathrm{~km}$ belong to NATURA 2000 protected areas. From that point of view the approximate ratio between Bulgaria and Greece is 2 to 1.

- A particular disadvantage of the NATURA 2000 ecological network in Greece is the fact that the areas around the small rivers are not included in protected areas - for example Aterenska River, Luda River, and even the right bank of Mesta River do not fall within protected areas on Greek territory which is contrary to the agreements of the Ramsar Convention.

- Future management of NATURA 2000 protected areas will probably require some optimization in the scope and enforcement of principles on behalf of EEC to be complied by all countries involved in NATURA 2000 ecological network, and this is particularly relevant for the future enlargement of the European Union, which will include Macedonia, Serbia and Turkey.

\section{Acknowledgements}

Part of the investigation is carried out under the project "Mapping and identification of conservation status of natural habitats and species - Phase I" within Environment Operational Programme $2007-2013$. 


\section{Assen Assenov}

\section{References}

Anonymous 2002. Biological Diversity Act, Promulgated, State Gazette No77/9.08.2002, last amended and supplemented, SG No19/8.03.2011, effective 9.04.2011.

Anonymous 1992. Council Directive 92/43 EEC. 1992.

Anonymous1979. Council Directive 79/409 CEE . 1979.

Anonymous1995-2012. NATURA 2000 Interactive Map - European Environmental Agency, 1995 - 2012

Assenov, A.,2012. Mountain Perica (Beslenski Rid) Partof Protectet Area "Dolna Mesta" - BG 0000220.Annuarie de L'Universite de Sofia "St. Kliment Ohridski”. Faculte de Geologie et Geographie, Livre 2 - Geographie, Tome 105, Sofia. (in print).

Assenov, A., M. Lyubenova, K .Pachedjieva, N. Georgieva. 2012. Conservation significance of the border stretch of Dospat River Valley. Ecology Seminar - April 26 -27, 2012. Sofia, (in print).

Bondev, I., 1991.The Vegetation of Bulgaria, Map 1 : 600000 with Explanatory Text. St. Kliment Ohridski Univesity Press. Sofia.

Borissova, B., B. Koulov. 2010. Environmental Policy Integration for Sustainable Regional Development. Proceedings from International Conference: Geography and Regional Development. Bulgarian Academy of Sciences, National Institute of Geophysics, Geodesy and Geography, Department of Geography.

Dimopoulos et al. 2012. Pers. comm. 2012: Checklist of the Vascular Plants of Greece, currently in progress.

Georghiou K, Delipetrou P. 2010 Patterns and traits of the endemic plants of Greece. Botanical Journal of the Linnean Society 162, 130-422.

Grant,V, 1985. The evolutionary Process. A Critical Review of Evolutionary Theory. Columbia University Press, New York.

Meshinev, T., Apostolova, I. 2005. Habitats in Bulgaria. In: Proceedings of national workshop "Modern state of the biodiversity in Bulgaria - problems and perspectives", Sofia, 3 - 4 May 2004. DRAGON studio, 351 - 373 (in Bulgarian).

Petrova, A., V. Vladimirov. 2010. Balkan endemics in the Bulgarian flora. PHYTOLOGIA BALCANICA 16 (2): 293 - 311 Sofia.

Strid, A., Tan K. 1997 Flora hellenica 1. Königstein: Koeltz Scientific Books.

Strid, A., Tan K. 2002 Flora hellenica 2. Ruggell: Koeltz Scientific Books.

Tan, K., Iatrou G.2001 Endemic plants of Greece, the Peloponnese. Gads Publishers Ltd, Copenhagen, 479 pp. 